\title{
Jurist-Diction
}

Volume 4 No. 1, Januari 2021

\section{Upaya Perlindungan Hutan Konservasi Atas Pemberian Izin Pemanfaatan Panas Bumi}

\author{
Abdi Muttaqien \\ Abdimutt@gmail.com \\ Universitas Airlangga
}

\begin{abstract}
How to cite:
Abdi Muttaqien 'Upaya

Perlindungan Hutan

Konservasi Atas Pemberian Izin Pemanfaatan Panas Bumi' (2021) Vol. 4 No. 1 Jurist-

Diction.

Histori artikel:

Submit 9 November 2020; Diterima 18 Desember 2020; Diterbitkan 5 Januari 2021.

DOI:

10.20473/jd.v4i1.24289

p-ISSN: $2721-8392$

e-ISSN: $2655-8297$
\end{abstract}

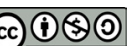

\begin{abstract}
This article was written on the theme of forestry and geothermal. This thesis focuses on efforts to protect conservation forest areas which are currently possible to be used as geothermal land use. As it is known, conservation area is one of the areas that serves as a preservation and preservation for a habitat of rare plants and animals. However, the use of geothermal energy is also important because the utilization of geothermal energy is one of the country's efforts to ensure the availability and security of national energy. Considering that at this time the biggest energy consumption at this time was still using fuel derived from fossil fuels whose supply was decreasing.

Keywords: Forestry; Geothermal; Conservation Area; Permit.
\end{abstract}

\begin{abstract}
Abstrak
Artikel ini ditulis dengan tema kehutanan dan panas bumi. Penulisan ini berfokus mengenai upaya perlindungan kawasan hutan konservasi yang pada saat ini dimungkinkan untuk digunakan sebagai lahan pemanfaatan panas bumi. Seperti yang diketahui kawasan konservasi merupakan salah satu kawasan yang berfungsi sebagai pengawetan dan pelestarian bagi suatu habitat flora maupun fauna. Namun pemanfaatan panas bumi juga merupakan satu hal yang penting dikarenakan pemanfaatan panas bumi ini merupakan salah satu upaya negara untuk menjamin ketersediaan dan ketahanan energi nasional. Mengingat pada saat ini konsumsi energi terbesar pada saat ini masih menggunakan bahan bakar yanng berasal dari fosil yang persediannya makin berkurang.

Kata Kunci: Kehutanan; Panas Bumi; Kawasan Konservasi; Izin.
\end{abstract}

Copyright $(\subset 2021$ Universitas Airlangga

\section{Pendahuluan}

Indonesia sebagai negara yang kaya akan kandungan cadangan sumber daya alam menjadikan salah satu negara yang memiliki potensi besar untuk memajukan perokonomian negara melalui sektor sumber daya alam. Dengan banyaknya kandung sumber daya alam di dalam bumi Indonesia seharusnya dapat dimanfaatkan dengan baik untuk kemajuan negara ini. Sebagaimana terdapat padda dalam Pasal 33 ayat (3) Undang - Undang Dasar Negara Republik Indonesia Tahun 1945 yang menyatakan bahwa: "Bumi dan air dan kekayaan alam yang terkandung didalamnya 
dikuasai oleh negara dan dipergunakan untuk sebesar besar kemakmuran rakyat".

Negara memiliki kekuasaan atas sumber daya alam yang tersebar pada seluruh kawasan Indonesia untuk selanjutnya dapat dimanfaatkan dengan sebak-baiknya. Dengan kata lain hal ini makna dari dikuasai negara adalah pengelolaan sumber daya yang terkandung didalam bumi Indonesia agar hasil dari pemanfaatannya dapat digunakan untuk kepentingan dan kemakmuran rakyat seluas-luasanya. ${ }^{1}$ Dalam hal ini makna dari dikuasai oleh negara adalah merupakan penguasaan yang dapat dilakukan oleh negara atas sumber daya alam yang dapat dimanfaatkan untuk kepentingan luas.

Sektor energi nasional yang memiliki potensi besar untuk dimaksimalkan adalah melalui panas bumi, Panas Bumi adalah sumber energi panas yang terkandung di dalam air panas, uap air, serta batuan bersama mineral ikutan dan gas lainnya yang secara genetik tidak dapat dipisahkan dalam suatu sistem Panas Bumi. Dalam Undang - udang Nomor 21 Tahun 2014 Tentang Panas Bumi mengatur mengenai pemanfaatan pemanfaatan energi panas bumi. Dalam hal ini dapat terlihat dalam Pasal 5 ayat (1). Pemerintah sendiri mengatur untuk pemanfaatan panas bumi pada beberapa kawasan yang memerlukan izin khusus salah satu pada kawasan hutan konservasi dimana pada kawasan ini sekiranya perlu pengawasan dan penggunaan kawasan ini tidak merusak fungsi asli dari kawasan hutan konservasi ini sendiri baik untuk pemanfaatan langsung maupun tidak langsung. Perlu diingat hingga saat ini masih terdapat hambatan-hambatan yang menyebabkan kurangnya pemanfaatan panas bumi untuk dijadikan sektor unggulan dalam inventasi di Inonesia selain dapat dimanfaatkan menjadi sumber tenaga untuk pembangkit listrik tenaga panas bumi dapat pula dijadikan sektor pariwisata dalam pemanfaatan panas bumi. Pemanfaatan panas bumi juga dapat dikatakan sebagai salah satu sumber energi yang tidak banyak menimbulkan kerusakan lingkungan yang ada di sekitarnya.

Persediaan bahan bakar fosil yang makin hari makin berkurang dan sifatnya yang dapat mencemari lingkungan maka penggunaannya sudah seharusnya dapat

\footnotetext{
1 Adrian Sutedi, Hukum Pertambangan (Sinar Grafika 2012).[24].
} 
dikurangi. Panas bumi sebagai sumber energi yang terbarukan dapat dimanfaatkan sebagai sumber energi litrik yang dapat menggantikan batubara dan memiliki tingkat pencemaran yang lebih ramah lingkungan jika dibandingkan dengan barubara. Jika ditunjang dengan pemanfaatan yang baik maka pemanfaatan panas bumi menjadi satu hal yang menjanjikan apabila dilakukan pemanfaatan mengingat besarnya cadangan yang terkandung pada kawasan nusantara.

Bila seluruh potensi titik panas bumi ini dapat dimaksimalkan dengan baik potensi ini dapat menghasilkan energi listrik yang dapat digunakan hingga lebih dari 28.000 megawatt. Indonesia sendiri memiliki potensi yang sangat besar pada sektor panas bumi. Sejauh ini telah ditemukan sebanyak 56 dengan potensi panas bumi pada kawasan hutan lindung, dan terdapat sekitar 50 titik potensi panas bumi yag dapat dmanfaatkan pada kawasan hutan produksi. Selain itu masih terdapat sekiranya sebanyak 145 titik yang berpotensi pada areal pengguaan lain yang dapat dimaksimalkan sebagai seumber panas bumi. ${ }^{2}$

Kemudian diatur pada Pasal 38 Ayat (1) Undang-Undang Nomor 41 Tahun 1999 tentang Kehutanan ditekankan bahwasanya kawasan hutan yang dapat digunakan untuk dilakukan pembangunan untuk aktivitas diluar aktivitas kehutanan dapat dilakukan pada kawasan hutan produksi maupun pada hutan lindung. Dengan demikian dalam pasal ini dapat dikatakan bahwa ada pembatasan kawasan hutan untuk digunakan sebagai kawasan hutan untuk kepentingan pembangunan di luar kegiatan kehutanan. Oleh karenanya dirasa perlu adanya penjelasan atas pemberian izin pemanfaatan sumber panas bumi untuk pemanfaatan secara tidak langsung pada kawasan hutan konservasi.

Dirasa perlu adanya upaya dalam mempertahankan fungsi dari kawasan hutan konservasi yang digunakan sebagai area pemanfaatan panas bumi hal ini tentunya perlu suatu keseimbangan karena adanya dua kepentingan didalamnya yang pertama merupakan pengusahaan panas bumi yang diutamakan sebagai pembangkit listrik

\footnotetext{
2 Noverius Laoli, KLHK Gali Potensi Panas Bumi di Hutan Konservasi, <https://www. rimbawan.com/berita/klhk-gali-potensi-panas-bumi-di-hutankonservasi/ $>$. diakses pada tanggal 7 Agustus 2020, pukul 19.45.
} 
yang menjadikannya sektor yang vital bagi negara sebagai upaya dari ketahanan dan ketersediaan energi nasional namun disamping itu keberadaan dari fungsi kawasan konservasi itu sendiri harus tetap terjaga mengingat adanya satu ekosistem yang harus dijaga didalamnya oleh karena itu pengaturan kedua hal ini sangatlah penting.

Pada penelitian ini menggunakan penelitan hukum yuridis normatif, yakni penelitian yang membahas dan membedah secara sistematis atas peraturan perundang-undangan yang berlaku pada saat ini. Dengan tujuan mendapatkan pembahsan yang secara sistematis atas peraturan perundang-undangan yang berkaitan dengan penelitian ini

\section{Kerangka Yuridis Izin Penggunaan Kawasan Hutan Konservasi untuk Pemanfaatan Panas Bumi.}

Menurut Black Law Dictionary kewenangan diartikan dalam pengertian yang lebih luas, bukan hanya dalam konteks untuk menjalankan kekuasaan, akan tetapi kewenangan diartikan kedalam konteks untuk menegakan dan menerapkan hukum, adanya ketaatan yang pasti, mengandung perintah, memutuskan, adanya pengawasan yuridiksi bahkan kewenangan dikaitkan dengan kewibawaan, kharisma bahkan kekuatan fisik. Wewenang merupakan konsep inti dalam hukum tata negara dan hukum administrasi negara. sebab didalam wewenang tersebut mengandung hak dan kewajiban, bahkan di dalam hukum tata negara wewenang dideskripsikan sebagai kekuasaan hukum. Artinya hanya tindakan yang sah yang mendapat kekuasaan hukum. Dalam hukum administrasi terdapat tiga jenis sumber kewenangan yang dikenal yakni atribusi, mandat dan delegasi.

Atribusi merupakan pemberian wewenang yang dimiliki pemerintahan oleh pembuat undang-undang kepada organ pemerintahan. Hal ini diatur dalam UndangUndang Nomor 30 Tahun 2014 tentang Administrasi Pemerintahan, atribusi adalah pemberian Kewenangan kepada Badan dan/atau Pejabat Pemerintahan oleh UndangUndang Dasar Negara Republik Indonesia Tahun 1945 atau Undang-Undang.

Delegasi menurut Undang-Undang Nomor 30 Tahun 2014 tentang Adiministrasi Pemerintahan Pasal 1 angka 23 delegasi merupakan pelimpahan 
Kewenangan dari Badan dan/atau Pejabat Pemerintahan yang lebih tinggi kepada Badan dan/atau Pejabat Pemerintahan yang lebih rendah dengan tanggung jawab dan tanggung gugat beralih sepenuhnya kepada penerima delegasi.

Mandat terjadi jika organ pemerintahan mengizinkan kewenangannya dijalankan oleh organ dengan tetap menalankan kewenangan atas nama pemberi mandat. Mengacu pada Undang-Undang Nomor 30 Tahun 2014 tentang Administrasi Pemerintahan, mandat merupakan pelimpahan kewenangan dari Badan dan/atau Pejabat Pemerintahan yang lebih tinggi kepada Badan dan/atau Pejabat Pemerintahan yang lebih rendah dengan tanggung jawab dan tanggung gugat tetap berada pada pemberi mandat.

Selain itu secara atribusi pada Pasal 14 ayat (4) Undang-Undang Nomor 23 Tahun 2014 tentang Pemerintahan Daerah urusan pemerintahan pada bidang yang berkaitan dengan pemanfaatan langsung panas bumi pada daerah kabupaten/ kota menjadi kewenangan pemerintah daerah, kabupaten/kota tersebut. Berbeda dengan kewenangan pemerintah pusat, pemerintah daerah hanya dapat menerbitkan perizinan dalam kegiatan pemanfaatan panas bumi hanya untuk kegiatan langsung, yang tidak merubah sumber panas bumi tersebut menjadi energi listrik. Dalam gal ini perizinan ini dilakukan baik digunakan untuk kegiatan ekowisata maupun agro wisata, baik pada kawasan hutan lindung maupun kawasan hutan produksi yang terdapat pada lintas wilayah pada provinsi tersebut.

Pemerintah Daerah tidak dapat mengeluarkan izin panas bumi secara langsung pada kawasan hutan konservasi dikarenakan segala perizinan pemanfaatan panas bumi yang menggunakan kawasan hutan konseervasi menajadi kewenangan pemerintah pusat. Sehingga dalam hal ini secara perizinan pemanfaatan panas bumi yang terdapat pada kawasan hutan konservasi tetap mengacu pada Undang-Undang Nomor 21 Tahun 2014 tentang Panas Bumi yang memiliki wewenang mengeluarkan izin pemanfaatan langsung panas bumi pada kawasan tersebut menjadi kewenangan pemerintah, namun yang perlu diingat bahwa secara substansi perundang-undangan hal yang mengatur mengenai pemanfaatan langsung tetap pada pengaturan UndangUndang Nomor 23 Tahun 2014 tentang Pemenrintahan Daerah. 
Pemerintah dalam hal ini lebih memfokuskan pada pemanfaatan panas bumi untuk pemanfaatan tidak langsung yang digunakan sebagai pembangkitan tenaga listrik, sebagaimana amanat dari Undang-Undang Nomor 21 Tahun 2014 tentang Panas Bumi. Adapun kewenangan dalam hal pemanfaatan panas bumi untuk pemanfaatan secara langsung diserahkan kepada pemerintah pada tingkat daerah sesuai dengan kewenangannya. Dalam pemenuhan ketahanan dan ketesedian energi nasional pemerintah harus mempercepat pengembangan pada sektor panas bumi. Pemerintah selain diberi kewenangan untuk melakukan Survei Pendahuluan dan Eksplorasi juga diberi kewenangan untuk melakukan Eksploitasi dan Pemanfaatan. ${ }^{3}$

Di Jawa Timur sendiri potensi panas bumi di Jawa Timur mencapai 1372 MW dan setidaknya tersebar disebanyak 13 titik potensi panas bumi yang dapat dimanfaatkan dan dimana 8 diantaranya saat ini telah dijadikaan menjadi wilayah kerja panas bumi untuk kemudian dapat dilakukan pemanfaatan. Jawa timur memiliki Peraturan Daerah Provinsi Jawa Timur Nomor 6 Tahun 2019 tentang Rencana Umum Energi Daerah Provinsi Jawa Timur Tahun 2019 - 2050, dimana dalam peraturan daerah ini pengembangan panas bumi merupakan salah satu hal yang diperhatikan mengingat panas bumi merupakan sumber daya terbarukan yang dapat digunakan terus menerus.

Dalam pemanfaatan panas bumi untuk pemanfaata secara tidak langsung telah diatur dalam Peraturan Pemerintah Republik Indonesia Nomor 7 Tahun 2017 tentang Panas Bumi untuk Pemanfaatan Tidak langsung. Peraturan Pemerintah ini untuk melaksanakan ketentuan yang mengatur tentang panas bumi untuk pemanfaatan secara tidak langsung yang terdapat dalam Undang-Undang Nomor 21 Tahun 2014 tentang Panas Bumi

Setiap orang atau badan usaha wajib memiliki izin pengusahaan panas bumi untuk menyelenggarakan kegiatan panas bumi. Dengan izin yang diberikan ini dapat dikatakan sebagai persetujuan yang diberikan oleh pejabat yang berwenang kepada setiap orang atau badan usaha untuk melaksanakan setiap kegiatan yang berkaitan

${ }^{3}$ Muhamad Azhar Suhartoyo, 'Aspek Hukum Kebijakan Geothermal di Indonesia' (2015) 11 Law Reform.[125]. 
dengan pana bumi. Mengenai perizinan pengusahaan panas bumi ini sendiri diatur dalam Pasal 11 hingga Pasal 56 Undang-Undang Nomor 21 Tahun 2014 tentang Panas Bumi, juga diatur dalam Peraturan Pemerintah Nomor 7 Tahun 2017 tentang Panas Bumi Untuk Pemanfaatan Tidak langsung.

Sesuai dengan cara pemanfaatannya izin pengusahaan panas bumi terbagi menjadi dua, yakni izin pemanfaatan langsung dan izin panas bumi (IPB). Dalam hal ini izin panas bumi ini izin yang ditentukan pada wilayah kerja terntentu untuk melakukan pengusahaan panas bumi untuk pemanfaatan tidak langsung.

Adapun izin panas bumi diberikan untuk melaksanakan kegiatan:

1) Eksplorasi;

2) Eksploitasi;

3) Pemanfaatan.

Dalam pemanfaatan panas bumi selain perinan yang telah disebutkan diatas setiap pemohon izin juga harus memiliki izin lingkungan dan juga izin pemanfaatan kawasan hutanuntuk dapat melengkapi memperoleh izin pengusahaan panas bumi. ${ }^{4}$

Pemberian izin pengusahaan panas bumi diterbitkan oleh pejabat yang berwenang diatur dalam Pasal 11 Undang-Undang Nomor 21 Tahun 2014 tentang Panas Bumi bahwa yang berwenang dalam pemberian izin pengusahaan panas bumi meliputi:

1) Menteri;

2) Gubernur;

3) Bupati/Walikota.

Setiap pejabat berwenang menerbitkan izin sesuai dengan yang tertuang dalam Undang-Undang Nomor 21 Tahun 2014 tentang Panas Bumi. Dalam hal ini menteri wajib memberikan persetujuan dalam setiap pemberian izin pengusahaan panas bumi.

Adanya konflik norma antara Pasal 38 ayat (1) Undang-undang Nomor 41 Tahun 1999 tentang Kehutanan yang menyebutkan bahwa kegiatan pembangunan

\footnotetext{
4 Salim HS, Pengantar Hukum Sumber Daya Alam (Rajawali Pers 2018).[253].
} 
diluar kegiatan kehutanan lainnya hanya dapat dilakukan pada hutan produksi dan hutan lindung dengan Pasal 5 ayat (1) Undang-undang Nomor 21 Tahun 2014 tentang Panas Bumi yang menyatakan bahwa kegiatan pengusahaan panas bumi dapat dilakukan pada kawasan hutan konservasi. Hal ini tentunya merupakan dua hal yang bertolak belakang dalam penggunaan kawasan hutan konservasi sekiranya diperlukan adanya harmonisasi aturan mengenai kedua ketentuan ini.

Harmonisasi pengaturan pada sektor pengusahaan panas bumi dengan perlindungan hutan konservasi adalah suatu upaya untuk membenahi adanya norma yang bertentangan. Harmonisasi yang dimaksudkan merupakan suatu cara untuk menyelaraskan mengenai pengaturan yang terkait dengan pemanfaatan energi panas bumi dan juga perlindungan hutan konservasi. Sehingga nantinya tujuan dari masingmasing norma tersebut dapat berjalan beriringan. Hal ini karena tujuan pembentukan peraturan perundang-undangan dalam bidang sumber daya alam adalah memanfaatkan sumber daya alam untuk sebesar-besarnya kemakmuran rakyat.

Oleh karena itu sekiranya diperlukan adanya perubahan atas Pasal 38 ayat (1) UU No. 41/1999 tentang Kehutanan dalam hal ini ketika melihat bahwa pengusahaan panas bumi ini bukan termasuk kegiatan pertambangan sebagaimana pada umumnya pengusahaan panas bumi ini merupakan kegiatan yang tidak menimbulkan efek kerusakan lingkungan yang besar dan dalam pemanfaatan panas bumi juga tidak menghasilkan limbah yang dapat meruusak ekosistem di sekitarnya. Selain itu pengusahaan panas bumi ini juga merupakan pengusahaan yang berjalan seiringan dengan prinsip pembangunan berkelanjutan sehingga pembangunan pada kawasan hutan konservasi dapat dilakukan.

Pada saat ini pengaturan mengenai pelaksanaan pengusahaan panas bumi pada kawasan konservasi untuk pemanfaatan tidak langsung juga secara khusus telah diatur dalam Peraturan Pemerintah Nomor 7 Tahun 2017 tentang Panas Bumi Untuk Pemanfaatan Tidak Langsung, sehingga pada penggunaan kawasan hutan konservasi dapat dilaksanakan dengan tetap menjaga keaslian kawasan hutan konservasi tersebut sebagaimana sesuai dengan Pasal 12 Undang-undang Nomor 5 Tahun 1990 tentang Konservasi Sumber Daya Alam Hayati dan Ekosistemnya yang 
menyebutukan bahwa pengawetan keanekaragaman tumbuhan dan satwa beserta ekosistemnya, dilaksanakan dengan menjaga keutuhan kawasan agar tetap dalam keadaan asli. Sehingga disamping pengusahaan panas bumi tersebut fungsi dari kawasan hutan konservasi tersebut juga dapat tetap berjalan.

Selain itu penggunaan energi fosil juga tidak sejalan dengan prinsip pembangunan berkelanjutan dimana energi fosil yang akan habis pada masa yang akan datang. Ada dua konsep yang penting dalam prinsip tersebut. Pertama, konsep kebutuhan (needs), terutama kebutuhan dasar pada saat ini, dan Kedua, ide keterbatasan yang didasarkan pada kemajuan tekhnologi dan organisai sosial untuk menetapkan daya dukung dari lingkungan yang mampu menopang kehidupan generasi masa sekarang dan generasi masa depan.

Penggunaan kawasan hutan konservasi sebagai kawasan pemanfaatan panas bumi juga merupakan sebagai kegiatan yang berada pada sektor penting yakni sebagai usaha negara untuk menjamin ketahanan dan ketersediaan energi nasional. Selain itu pada pengusahaan bumi ini juga selain pada pemerintahan pusat pemerintah daerah juga dapat ketersinambungan dengan adanya pajak daerah yang dibayarkan oleh pengusahaan panas bumi tersebut.

Selain itu juga belum adannya peraturan yang mengatur mengenai indikator mengenai kerusakan kawasan hutan konservasi apabila kawasan hutan konservasi digunakan sebagai kawasan pengusahaan panas bumi. Hal ini tentunya perlu dirumuskan sehingga apabila dalam kegiatan pengusahaan panas bumi tersebut tidak terjadi pelanggaran.

\section{Penegakan Hukum Penggunaan Hutan Konservasi atas Pemanfaatan Panas Bumi.}

Menurut Undang-Undang Nomor 41 Tahun 1999 tentang Kehutanan, terdapat ketentuan mengenai perlindungan hutan dan kawasan hutan sebagimana diatur dalam Pasal 47 Undang-Undang Nomor 41 Tahun 1999 yang menyebutkan kegiatan perlindungan ini guna mencegah terjadinya kerusakan hutan baik akibat adanya kebakaran hutan adanya hama dan mencegah terjadinya adanya perambahan hasil hutan yang disebabkan oleh perbuatan manusia dalam pengusahaan hutan tersebut. 
Selain itu adanya perlindungan hutan ini memiliki usaha guna tetap menjaga hakhak negara maupun masyarakat dan individu atas hutan dan kawasan hutan, hasil hutan, investasi dan perangkat yang berhubungan dengan pengelolaan hutan.

Fungsi dari adanya peraturan yang mengatur mengenai pemakaian hutan ini sendiri sebagai upaya untuk pengendalian penggunaan hutan serta menjadi pedoman dalam melakukan kegiatan pada kawasan hutan. ${ }^{5}$ Adapun kegiatan dalam usaha perlindungan hutan memiliki tujuan untuk tetap menjaga kelestarian dari hutan itu sendiri beserta lingkungan yang ada didalamnya, guna fungsi lindung, fungsi produksi, dan fungsi konservasi dapat tercapai secara optimal dan lestari.

Perlindungan ini memiliki tujan untuk menjaga kelestarian dan kealamian kawasan hutan termasuk karena adanya tindakan yang dilakukan oleh manusia termasuk dalam pemanfaatan hutan untuk melakukan penambangan dan eksplorasi serta eksploitasi tanpa adanya izin. Perlindungan hutan ini dapat dilakukan dengan baik juga didukung dengan pengawasan yang ketat. Hal ini guna untuk mengawasi kegiatan yang dilakukan sesuai dengan perizinan yang berlaku, agar tidak terjadi pelanggaran.

Apabila terjadi sengketa kehutanan terdapat dua penyelesaian sengketa baik melalui pengadilan untuk tindak pidana maupun diluar pengadilan. Dimana dalam hal ini apabila adanya laporan mengenai adanya tindak pidana maka penyidikan dapat dilakukan selain oleh penyidik dari kepolisian dapat dilakukan oleh penyidik Pegawai Negeri Sipil yang diangkat dari Pegawai Negeri Sipil pada lingkungan Kementerian yang mengurusi bidang kehutanan, sebagai mana ketentuan ini terdapat pada Pasal 77 Undang - Undang Nomor 41 Tahun 1999 tentang Kehutanan. ${ }^{6}$

Penegakan hukum ini sendiri adalah sebuah upaya untuk mencapai ketaatan terhadap peraturan yang berlaku baik bagi individual maupun secara umum. Penagakan hukum kehutanan sendiri dilakukan dengan cara pengawasan dan juga penerapan sanksi terhadap pelanggaran yang terjadi, sanksinya yang diberikan

5 Suparto Widjoyo, Refleksi Matarantai Pengaturan Hukum Pengelolaan Lingkungan secara Terpadu (Studi Kasus Pencemaran Udara) (Airlangga University Press 2005).[138].

6 Ernest Runtukahu, 'Hambatan dan Upaya Pembenahan Penegakan Hukum terhadap Kejahatan Di Bidang Kehutanan’ (2015) 2 Lex et Socieatis.[65]. 
sesuai dengan pelanggaran yang terjadi baik sanksi administrasi, keperdataan maupun kepidanaan. ${ }^{7}$ Penegakan hukum ini meruapakan hal yang penting untuk mencapai ketaatan pada suatu peraturan perundang-undangan.

Penegakan hukum lingkungan adminidtrasi berkaitan dengan penegakan hukum lingkungan oleh lembaga pemerintahan. Penegakan hukum lingkungan kepidanaan dilakukan melalui prosedur yuridis peradilan pidana yang dimulakan dengan adanya penyidikan dan penuntutan keadaan adanya kedua penegakan hukum ini bersifat saling melengkapi satu sama lain. ${ }^{8}$ Adapun penegakan hukum keperdataan sendiri merupakan bersifat individu apabila dirasa terjadi kerugian bagi suatu pihak. Adapun dalam penegakan hukum keperdataan ini dengan adanya ganti rugi atas adanya kerugian yang dialami oleh pihak yang dirugikan akibat adanya perbuatan melanggar hukum. ${ }^{9}$

Tentunya dalam penegakan hukum terkait kehutanan ini sendiri tidak lepas dari aparatur penegak hukum itu sendiri. Dalam penegakan hukum ini aparatur penegak hukum tidak hanya terdiri dari kepolisian, jaksa, dan kepengacaraan saja namun juga instansi terkait yang memberikan izin. Penyelesaian sengketa sebagai upaya dari pengendalian ini dapat dilakukan dengan dua hal dimana dapat dilakukan diluar pengadilan yang merupakan langkakh awal jika terjadi sengketa, dan dilakukan melalui jalur pengadilan apabila melalui langkah penyelesaian sengketa alternatif tidak mencapai kesepakatan. ${ }^{10}$

Penerapan sanksi meruapakan bagian dari adanya penegakan hukum, penerapan sanksi administrasi merupakan langkah setelah dilakukannya pengawasan, dalam penerapan sanksi administrasi ini ada beberapa sanksi yang dapat diberikan kepada pelanggar diantaranya adalah:

a. Paksaan pemerintah atau tindakan paksa;

b. Uang paksa;

c. Penutupan tempat usaha;

\footnotetext{
7 Suparto Widjoyo, Op, Cit.[483].

8 ibid.

9 ibid.[484].

${ }^{10}$ ibid. [487].
} 
d. Penghentian kegiatan mesin perusahaan;

e. Pencabutan izin. ${ }^{11}$

Dalam penegakan hukum ini dapat bersifat preventif maupun represif, dengan adanya penegakan hukum preventif memiliki arti bahwa pengawasan dilakukan untuk melihat bahwa tidak adanya pelanggaran yang terjadi dan dalam hal ini dapat dilakukan pemberian penyuluhan untuk menaati peraturan yang berlaku. Sedangkan penegakan hukum yang bersifat represif ini dilakukan apabila terjadinya perbuatan melanggarar peraturan perundang-undangan. ${ }^{12}$ Tentunya dalam penegakan hukum tidak lepas dari penerapan sanksi yang diberikan atas terjadinya pelanggaran.

Dengan adanya penegakan hukum pada bidang kehutanan ini bertujuan untuk mengurangi pelanggaran yang terjadi sehingga pelaksanaan dari perlindungan hutan itu sendiri dapat dilakukan dengan baik, hal ini juga harus dibarengi dengan kordinasi yang baik antara penegak hukum itu sendiri, baik kepolisian dengan masyarakat. Upaya pemulihan atas terjadinya kerusakan pada suatu ekosistem terdapat tiga upaya dalam mengembalikan ekosistem tersebut yaitu:

1. Reklamasi yaitu melakukan pemulihan atas ekosistem yang terganggu baik dilakukan dengan pohon - pohon monokultural agar fungsi perlindungan pada hutan tersebut dapat dibangun kembali;

2. Rehabilitasi dengan mengembalikan produktivitas pada kawasan hutan dengan mengembalikan tumbuhan maupun satwa yang sebelumnya terdapat pada kawasan tersebut;

3. Restorasi yaitu kembali membangun keanekaragaman hayati pada kawasan tersebut agar struktur pada hutan kembali sedia kala. ${ }^{13}$

Dalam upaya pelestarian kawasan konservasi ini tentunya juga diperlukan adanya suatu upaya guna tetap menjaga suatu habitat yang dilindungi didalam kawasan konservasi tersebut. Hal ini tentunya diperlukan suatu standarisasi yang

11 ibid. [501].

12 ibid.[483].

${ }^{13}$ Sugiharto: Rehabilitasi, Reklamasi, Restorasi, dan Recovery Hutan, <http://agroindonesia. co.id/2019/11/rehabilitasi-reklamasi-restorasi-dan-recovery-hutan/>. diakses pada tanggal 8 Agustus 2020, pukul 20.30. 
memungkinkan tetap berjalannya pemanfaatan yang berlangsung pada kawasan konservasi namun disamping itu juga tetap memperhatikan dan mempertahankan fungsi pengawetan habitat flora dan fauna yang terdapat dalam kawasan konservasi tersebut. rakat.

Selain itu pada saat ini juga belum ada peraturan yang menagtur mengenai indikator kerusakan kawasan hutan konservasi apabila kawasan hutan konservasi tersebut dilakukan suatu pemanfaatan baik untuk pemanfaatan panas bumi maupun pemanfaatan lainnya yang menggunakan kawasan hutan konservasi. Hal ini diperlukan guna tetap menjaga keaslian dan keasrian kawasan hutan konservasi itu sendiri sehingga dalam penggunaan kawasan hutan konservasi untuk suatu pemanfaatan dapat berjalan sesuai prosedur dan tidak merusak lingkungan kawasan hutan konservasi yang sedang digunakan.

Dalam upaya pelestarian kawasan konservasi ini tentunya juga diperlukan adanya suatu upaya guna tetap menjaga suatu habitat yang dilindungi didalam kawasan konservasi tersebut. Hal ini tentunya diperlukan suatu standarisasi yang memungkinkan tetap berjalannya pemanfaatan yang berlangsung pada kawasan konservasi namun disamping itu juga tetap memperhatikan dan mempertahankan fungsi pengawetan habitat flora dan fauna yang terdapat dalam kawasan konservasi tersebut.

Selain itu pada saat ini juga belum ada peraturan yang menagtur mengenai indikator kerusakan kawasan hutan konservasi apabila kawasan hutan konservasi tersebut dilakukan suatu pemanfaatan baik untuk pemanfaatan panas bumi maupun pemanfaatan lainnya yang menggunakan kawasan hutan konservasi.

Hal ini diperlukan guna tetap menjaga keaslian dan keasrian kawasan hutan konservasi itu sendiri sehingga dalam penggunaan kawasan hutan konservasi untuk suatu pemanfaatan dapat berjalan sesuai prosedur dan tidak merusak lingkungan kawasan hutan konservasi yang sedang digunakan.

Hal ini dikarenakan adanya perlindungan yang dilakukan pada suatu habitat pada suatu kawasan konservasi. Dengan memperhatkan standarisasi baik tingkat nasional maupun internasional tentunya hal ini sangat baik bagi pemanfaatan yang dilakukan ditengah kawasan konservasi namun fungsi dari kawasan konservasi tersebut tetap terjaga. 


\section{Kesimpulan}

Masih adanya konflik norma yang terjadi dalam pengaturan penggunaan hutan konservasi sebagai kawasan yang digunakan untuk kegiatan diluar kegiatan hutan lainnya dalam hal ini terdapat konflik norma pada Pasal 38 ayat (1) UU No. 41/1999 tentang Kehutanan yang menyatakan pembangunan pada kaawasan hutan hanya dapat dilaukan pada hutan produksi dan hutan lindung, sedangkan dalam Undang-Undang Nomor 21 Tahun 2014 tentang Panas Bumi tentang Panas Bumi Pasal 5 menyatakan bahwa kawasan hutan konservasi dapat digunakan sebagai kawasan pemanfaatan panas bumi. Oleh karena itu perlu dilakukan perubahan maupun revisi kepada pasal 38 ayat (1) UU No. 41/1999 tentang Kehutanan dikarenakan pemanfaatan panas bumi ini merupakan sektor yang penting mengingat pemanfaatan panas bumi ini tidak menimbulkan polusi dan dampak yang besar bagi lingkungan sekitar. Pada saat ini juga penggunaan sumber energi fosil yang masih besar dan cadangan yang makin berkurang pemanfaatan panas bumi perlu ditingkatkan mengingat energi panas bumi in merupakan sumber energi yang terbarukan dan tidak akan habis untuk generasi yang akan datang.

Dalam hal penggunaan kawasan hutan konservasi belum diatur mengenai indikator kerusakaan kawasan hutan konservasi. Hal ini perlu dirumuskan guna sebagai sarana dalam menjaga kawasan hutan konservasi yang ada di Indonesia khususnya dalam hal penggunaan kawasan hutan konservasi untuk pemanfaatan panas bumi. Sehingga perlu dirancangan suatu peraturan perundang - undangan yang mengatur mengenai indikator kerusakan hutan konservasi, hal ini tentunya sebagai satu upaya bagi kawasan hutan konservasi untuk menghindari terjadinya kerasukana pada kawasan hutan konservasi ini.

Pemerintah seyogyanya membuat standarisasi dalam hal menjaga kawasan hutan konservasi untuk tujuan tetap menjaga keaslian dan keasrian dari kawasan konservasi, hal ini dirasa sangat penting guna tetap menjaga fungsi dari konservasi untuk menjadi fungsi pengawetan unsur flora dan fauna yang ada didalamnya. Oleh sebab itu perlunya ada suatu standarisasi yang harus dipenuhi saat menggunakan 
kawasan hutan konservasi ini untuk tetap melestarikan flora dan fauna yang terdapat didalam kawasan hutan konservasi ini terlebih banyak spesies yang memang dilindungi dalam suatu kawasan hutan konservasi.

\section{Daftar Bacaan}

\section{Buku}

Adrian Sutedi, Hukum Pertambangan (Sinar Grafika 2012).

Direktorat Panas Bumi, Direktorat Jenderal EBTKE Pusat Sumber Daya Mineral, Batubara, dan Panas Bumi, Badan Geologi, Potensi Panas Bumi Indonesia Jilid 1 (Direktorat Panas Bumi Direktorat Jenderal Energi Baru, Terbarukan dan Konservasi Energi Kementerian Energi dan Sumber Daya Mineral 2017).

Salim HS, Pengantar Hukum Sumber Daya Alam (Rajawali Pers 2018).

Suparto Widjoyo, Refleksi Matarantai Pengaturan Hukum Pengelolaan Lingkungan secara Terpadu (Studi Kasus Pencemaran Udara) (Airlangga University Press 2005).

\section{Jurnal}

Ernest Runtukahu, 'Hambatan dan Upaya Pembenahan Penegakan Hukum terhadap Kejahatan Di Bidang Kehutanan', Jurnal Lex et Socieatis.

Muhamad Azhar, Suhartoyo, 'Aspek Hukum Kebijakan Geothermal di Indonesia', Jurnal Law Reform.

\section{Perundang-undangan}

Undang-Undang Dasar Negara Republik Indonesia Tahun 1945.

Undang-Undang Nomor 5 Tahun 1990 tentang Konservasi Sumber Daya Alam dan Ekosistemnya, (Lembaran Negara Republik Indonesia Tahun 1990, Nomor 49).

Undang - Undang Nomor 41 Tahun 1999 tentang Kehutanan, (Lembaran Negara Republik Indonesia Tahun 1999, Nomor 3888).

Undang - Undang Nomor 21 Tahun 2014 tentang Panas Bumi, (Lembaran Negara Republik Indonesia Tahun 2014, Nomor 217). 
Undang-Undang Nomor 23 Tahun 2014 tentang Pemerintahan daerah (Lembaran Negara Republik Indonesia Tahun 2014, Nomor 5587).

Peraturan Pemerintah Nomor 7 Tahun 2017 tentang Panas Bumi untuk pemanfaatan secara Tidak Langsung (Lembaran Negara Republik Indonesia Tahun 2017, No. 6023).

\section{Laman}

Noverius Laoli, 'KLHK Gali Potensi Panas Bumi di Hutan Konservasi, < <ttps://www.rimbawan.com/berita/klhk-gali-potensipanas-bumi- di- hutan-konservasi/>. diakses pada tanggal 7 Agustus 2020.

Sugiharto., 'Rehabilitasi, Reklamasi, Restorasi, dan Recovery Hutan', <http://agroindonesia.co.id/2019/11/rehabilitasi-reklamasirestorasi-dan- recovery-hutan/>. dikunjungi pada tanggal 8 Agustus 2020. 